\title{
POSLEDICE COVID-19 EPIDEMIJE NA VISOKO OBRAZOVANJE U SAD ${ }^{1}$
}

\author{
Nemanja Džuverović \\ Fakultet političkih nauka, Univerzitet u Beogradu
}

\begin{abstract}
SAŽETAK
Visoko obrazovanje u Sjedinjenim Američkim Državama je po većini kvantitativnih i kvalitativnih pokazatelja najbolje na svetu. Univerziteti u Sjedinjenim Američkim Državama, zajedno sa onima u Ujedinjenom Kraljevstvu, privlače najbolje studente ne samo iz Evrope već širom sveta uključujući najmnogoljudnije zemlje i rastuće ekonomije poput Kine, Indije, Brazila ili Indonezije. Istovremeno, priznati profesori i istraživači mahom rade u Sjedinjenim Američkim Državama, imajući u vidu sjajne uslove za rad i istraživanja. Međutim, snaga američkih univerziteta je istovremeno i njihova slabost u kontekstu COVID-19 epidemije. Većina univerziteta su privatni univerziteti koji u potpunosti zavise od tržišta, donacija, a ponajviše studentskih školarina. Epidemija je zaoštrila problem marketizacije obrazovanja u SAD imajući u vidu da većina studenata preispituje nastavak školovanja u novonastalim uslovima, ekonomske neizvesnosti koju epidemija donosi, kao i nesigurnog tržišta rada. Analizirajući studiju slučaja Nortvestern univerziteta, tekst se bavi ekonomskim i društvenim posledicama koje epidemija ima na visoko obrazovanje u Sjedinjenim Američkim Državama, kao i mogućim načinima njegovog prevladavanja.
\end{abstract}

KLJUČNE REČI: visoko obrazovanje, SAD, epidemija, COVID 19, Nortvestern, kriza

\section{Kontakt autora:}

Nemanja Džuverović, vanredni profesor na Fakultetu političkih nauka, Univerziteta u Beogradu. E-pošta: nemanja.dzuverovic@fpn.bg.ac.rs

1 Ranija verzija ovog teksta predstavljena je na konferenciji Udruženja za političke nauke Srbije - Saboru politikologa pod nazivom „Političke posledice pandemije”, održanom 26. i 27. 9. 2020. u Beogradu. 


\section{UVOD}

Visoko obrazovanje u Sjedinjenim Američkim Državama (SAD) uživa ugled da je najbolje na svetu. Da je ovakva tvrdnja utemeljena govori i većina relevantnih podataka o kvalitetu visokog obrazovanja. Po Akademskom rangiranju svetskih univerziteta (tzv. Šangajska lista), u prvih deset univerziteta na svetu čak osam dolaze iz SAD. Ukoliko se pogleda veći uzorak, od prvih 20 univerziteta petnaest dolaze iz ove države (ARWU 2020). Imajući u vidu da Šangajska lista uzima u obzir pretežno kriterijume koji su vezani za naučna istraživanja može se postaviti pitanje da li su univerzitetu u SAD podjednako dobri kada je u pitanju kvalitet nastave. S tim u vezi, Tajms lista svetskih univerziteta, koja se prevashodno bavi kvalitetom nastave, u prvih deset univerziteta ubraja sedam koji dolaze iz SAD, a u prvih dvadeset četrnaest koji dolazi sa severnoameričkog kontinenta (The Times 2020). ${ }^{2}$

Uspeh američkih univerziteta ne dolazi samo iz kvantitativnih pokazatelja već i usled obimnih sredstava koje najveći univerziteti poseduju u svojim fondacijama (engl. endowment). Tako, na primer, Harvard poseduje najveću fondaciju koja iznosi preko 40.00o.ooo.ooo američkih dolara. Nakon njega slede Jejl sa 30.0oo.ooo.ooo, Stanford sa 27.000.ooo.ooo, Prinston sa 25.000.00o.ooo dok poslednje mesto u prvih pet drži MIT sa fondacijom nešto većom od 17.00o.ooo.ooo američkih dolara (Kowarski 2020). Univerzitet Nortvestern (Northwestern) ima fondaciju u iznosu od 11.000.000.000 američkih dolara (Birenbaum 2020). Koliko su ova sredstva obimna govori i podatak da je godišnji istraživački budžet Harvard univerziteta veći od državnih budžeta za nauku svih država Zapadnog Balkana zajedno.

Snaga univerziteta u SAD se zasniva na njihovoj tržišnoj nadmoći. U Sjedinjenim Američkim Državama obrazovanje je viđeno, pre svega, kao roba koja se može i mora prodati. U savremenom, neoliberalizovanom, akademskom okruženju, ovakav stav posebno dolazi do izražaja, ali i uspeha. U kontekstu visokog obrazovanja u SAD, studenti su viđeni kao kupci koji su uvek u pravu i kojima se mora izaći u susret. Upravo zbog toga obrazovanje se posmatra kao sektor usluga gde zaposleni imaju obrazovnu, ali i tržišnu ulogu. U kontekstu COVID-19 epidemije (u nastavku epidemija) ovakav pristup dolazi u opasnost imajući u vidu negativne posledice koje epidemija ima po ekonomiju ove države. U skladu s tim, tekst se bavi kratkoročnim i dugoročnim posledicama koje epidemija ima po visoko obrazovanje u Sjedinjenim Američkim Državama.

2 Na obe liste najviša mesta zauzimaju univerziteti iz tzv. Lige bršljanja (Ivy League), koja uključuje Harvard, Jejl (Yale), Prinston (Princeton), Kolumbiju (Columbia), Braun (Brown), Dartmut (Dartmouth), Pensilvaniju (Pennsylvania) i Kornel (Cornell). 
Prvi deo rada posvećen je neoliberalnom univerzitetu, tj. uplivu tržišta u obrazovnu sferu. Drugi deo se bavi kratkoročnim posledicama epidemije po visoko obrazovanje u SAD, s tim što se posebno analiziraju ekonomske i društvene posledice. Treći deo analizira dugoročne trendove kada su u pitanju američki univerziteti. Na kraju se izlažu zaključna razmatranja i refleksije.

\section{NEOLIBERALNI UNIVERZITET}

Neoliberalni tržišni model, sveprisutan u razvijenim zemljama još od osme decenije 2o. veka, svoje utemeljenje je postepeno pronalazio i u visokom obrazovanju. Kao i u slučaju ekonomije, akademski neoliberalizam se postepeno širio da bi do početka 21. veka postao globalno prisutan i svojevrsna norma u načinu funkcionisanja univerziteta i visokog obrazovanja. Dolonec i Dolan (Dolonec and Doolan 2013, 328) navode da je u takvom okruženju akademski model oličen u sve manjim izdvajanjima države za obrazovanje i većem oslanjanju na privatne investicije i značajno uvećane školarine. U takvom modelu obrazovanje se vidi kao privatno dobro koje se kupuje kako bi se ostvario napredak pojedinca. Istovremeno, ceo sektor se preoblikuje da naliči korporativnom udruženju uvodeći menadžerske prakse i pozicije na univerzitetima, kvantifikacijom ciljeva koji se moraju postići, redovnim procenama uspeha koji se prevashodno zasnivaju na visini raspoloživih novčanih sredstava, kao i neprestanom insistiranju na proizvodnji znanja koje je prilagođeno potrebama tržišta.

Slično stanovište ima Gupta et al. $(2016,2-3)$ koji ističu da je neoliberalizacija obrazovanja dovela do prelaska finansiranja od strane države ka samofinansiranju, čime se zamagljuje granica između javnog i privatnog interesa. Takođe, insistira se na aplikativnom znanju gde se mnoge grane nauke vide kao nekorisne i neprilagođene savremenom tržištu rada. Pri tome, zauzima se stav da je zaposlenje jednostavno stvar svojevrsne primene tako stvorenog znanja na radnim mestima koja su idealtipski stvorena za navedenu vrstu posla. Navodi se da dolazi do prekida veza između proizvodnje znanja i upravljanja, pri čemu se pravi hijerarhija u kojoj menadžment zauzima vodeće pozicije i radi kao korporacija stvarajući pri tome kulturu rada koja je u suprotnosti sa vrednostima koje se neguju u akademskom okruženju. Na kraju, ističe se da primena ovakvog modela u obrazovanju dovodi do manjeg izdvajanja za istraživanja pogotovu za društvene i humanističke nauke koje se ne vide kao dovoljno aplikativne. Naglasak se stavlja na privid rada (konferencije, događaji, akademsko umrežavanje), a ne sadržinu koja proizlazi iz čitanja, pisanja i smislenih diskusija. Zajedno, ovakvi procesi dovode do ograničavanja akademskih sloboda u predavanju i istraživanju, ali i društvenih i ekonomskih sloboda studenata, istraživača i predavača koji sada u potpunosti zavise od menadžera. 
U svom istraživanju o naučnim konferencijama kao potrošnoj robi, Nikolson (Nicolson 2017, 15) ističe da je neoliberalizacija visokog obrazovanja dovela do promene profesionalne kulture, pri čemu je debata i intelektualna radoznalost ustupila mesto insistiranju na učincima kroz strateško planiranje, indikatore, kontrolu kvaliteta i akademske recenzije. Jedan od najboljih pokazatelja za ovakve navode su gore, spomenute rang liste gde se univerziteti rangiraju na državnom i globalnom nivou po raznim kriterijuma, sve u cilju njihove uporedivosti i kompeticije. Njegovi nalazi ukazuju da akademske konferencije postaju svojevrsno tržište gde rad koji se izlaže postaje instrument za oglašavanje proizvoda. Viđeno na taj način, ljudi koji učestvuju u diskusiji predstavljaju moguće kupce koji mogu imati koristi od ovakvog vida oglašavanja (Nicolson 2017, 49).

Na kraju, trebalo bi istaći i nalaze Džuverovića i Tepšića (2020) koji se bave ulogom neformalnih akademskih veza u balkanskim zemljama u cilju postizanja međunarodnih standarda koji se nameću u reformi visokog obrazovanja. Autori ističu da se neformalne veze koriste kako bi se imitirali standardi koji se zadaju tržišnom reformom univerziteta, pri čemu dolazi do imitacije razvoja zapadnih univerziteta i gde se usvaja forma bez ikakve sadržine usled nepostojanja ekonomskih i društvenih preduslova za tako nešto. Rezultat toga je tržišno orijentisano visoko obrazovanje koje se ne zasniva na visokim standardima već postaje svojevrsni simulakrum zapadnog akademskog sveta.

\section{Posledice EPIDEMIJE PO VISOKO OBRAZOVANJE U SAD}

\section{EKONOMSKE POSLEDICE}

Ekonomske posledice epidemije su svakako najvidljivije kada su u pitanju univerziteti u SAD. Još važnije, imajući u vidu visoku zavisnost od tržišta, one su se ispoljile u ranim fazama izbijanja epidemije.

Američki univerziteti su nedugo po izbijanju epidemije počeli da osećaju smanjenje broja studenata, što je došlo kao posledica zatvaranja velikih delova ekonomije u SAD i naglog skoka nezaposlenosti koje danas iznosi $8,5 \%$, dok je na vrhuncu krize iznosilo čak $15 \%$ (U.S. Bureau of Labor Statistics 2020). Ove brojke uporedive su sa onim iz vremena Velike depresije iz treće decenije 2o. veka. U ovakvim okolnostima veliki broj roditelja je izgubio posao ili nije mogao više da priušti uzimanje kredita za nastavak školovanja svoje dece3, što je dovelo do smanjenja broja studenata tokom trajanja akademske godine. 
Pored smanjenja broja studenata, kao posledica epidemije dolazi i do manjeg upisa novih studenata, pogotovu kada su u pitanju osnovne akademske studije. U uslovima velike nesigurnosti, zatvorenih kampusa, studiranja na daljinu i nepovoljne zdravstvene situacije, veliki broj dece se odlučuje da sačeka sa upisom do sledeće akademske godine ili da se upiše na državne univerzitete koji su lošiji po kvalitetu ali su besplatni, što se ispostavlja kao ključni faktor prilikom odluke za upis. Procenjuje se da gubitak američkih univerziteta, usled smanjenog broja novoupisane dece, doseže do 19.000.000.ooo dolara u akademskoj 2020/21. (Kim, Krishnan and Rounsaville 2020).

Smanjen broj postojećih i novoupisanih studenata jedna je strana problema. Druga se odnosi na odluku da se pređe na učenje na daljinu usled straha zbog širenja zaraze među studentskom i univerzitetskom populacijom. U tom smislu, prelazak na drugi način predavanja doneo je i znatan finansijski gubitak za američke univerzitete. Razlog za to je struktura školarina koja u sebe uključuje i troškove života, studentske domove, korišćenje sportskih terena i druge nenastavne troškove koje više nije moguće naplaćivati. Primera radi, jedna godina školovanja na Nortvestern univerzitetu iznosi 70.0oo američkih dolara od čega 15.0oo otpada na troškove života. Prelazak na nastavu na daljinu je samim tim smanjio prihode na ovoj visokoškolskoj ustanovi za preko $20 \%$.

Međutim, verovatno najveći ekonomski gubitak po američke univerzitete predstavlja smanjen broj međunarodnih studenata. Internacionalizovano studentsko (ali i predavačko) okruženje jedna je od glavnih odlika američkih univerziteta. Svake godine u SAD na studiranje dođe prosečno oko 1.100.ooo stranih studenata koji tokom svog školovanja potroše 40.000.000.00o dolara (Zhang and Stucka 2020). Od ukupnog broja preko $40 \%$ čine studenti koji dolaze iz NR Kine, dok za njima slede studenti iz Indije i Južne Koreje (Bastrikin 2020). Međutim, imajući u vidu porast sinofobije u SAD, koji je neretko podstaknut i od strane najviših vladinih zvaničnika, broj kineskih studenata koji dolazi u SAD na studiranje će biti značajno smanjen u narednim godinama. Porast netrpeljivosti prema kineskim studentima bio je očigledan i u ranim fazama epidemije kada je američka administracija optužila NR Kinu za prikrivanje dokaza, pa čak i veštačko kreiranje COVID-19 (BBC 2020), što je dovelo do napada na ljude koji su poreklom iz NR Kine i Azije širom Sjedinjenih Američkih Država (Cheung, Feng and Deng 2020). Sveukupno, procene su da će zbog posledica epidemije doći do smanjenja broja stranih studenata u SAD za 30-40\%, tj. oko 400.000 studenata, što će dovesti do gubitka od 2.400.00o.ooo dolara u školarinama (Brookings 2020), a ukupno od 15.0oo.ooo.ooo dolara, kada se uzmu u obzir celokupni troškovi stranih studenata tokom njihovog boravka u SAD (Zhang and Stucka 2020). 
POLITIČKE PERSPEKTIVE

ČLANCI I STUDIJE

Ovakva ekonomska situacija dovodi američke univerzitete u stanje strukturne krize iz koje se ne može izaći kratkotrajnim i brzim rešenjima. Primera radi, Nortvestern univerzitet je u akademskoj 2019/20. doživeo gubitak od 90.000.ooo američkih dolara (Morton Schapiro, imejl autoru, 5. avgust 2020), s tim što se slični negativni rezultat očekuje i u narednoj akademskoj godini. Međutim, ovakva negativna ekonomska situacija nije došla izolovano već je izazvala i društvene posledice koje su dodatno ugrozile pozicije visokoobrazovnih institucija u SAD.

\section{DRUŠTVENE POSLEDICE}

Epidemija, i sa njom izazvana ekonomska kriza, u SAD ogolila je još jedan problem sa kojim se američko društvo već decenijama suočava, a to je pitanje rasizma i međurasnih odnosa.

COVID-19 epidemija je dovela do zatvaranja ekonomije, ali istovremeno i do zavisnosti celokupne populacije od određenih zanimanja kao što su prodavci, vozači kamiona, dostavljači i svi oni koji omogućavaju nesmetano snabdevanje stanovništva (engl. Essential workers). Usled klasne podvojenosti u Sjedinjenim Američkim Državama, većinu radnika iz ovih industrija čine pripadnici Afro-američke i Latino manjinske zajednice. Takav njihov položaj doveo je i do veće ugroženosti od virusa, što je imalo za posledicu znatno višu stopu smrtnosti. U slučaju Afro-američke zajednice, ona je dvostruko veća od stope smrtnosti većinske belačke grupacije (Pilkington 2020). Ovde bi trebalo napomenuti da je struktura zaposlenosti dodatno podstaknuta obrazovnom nejednakošću, pri čemu manjinske zajednice imaju u proseku niži stepen obrazovanja. Takođe, visoka stopa smrtnosti ove dve grupe, objašnjava se i njihovom manjom pokrivenošću zdravstvenom zaštitom koja u SAD nije univerzalna već tržišno orijentisana (Džuverović 2020).

Nejednaka rasna izloženost posledicama epidemije izvedena je do krajnjih granica policijskom brutalnošću prema pripadnicima Afro-američke zajednice i ubistvom Džordža Flojda, što je oživelo pokret Crni životi (engl. Black Lives Matters, u nastavku BLM) tokom trajanja epidemije i organizovanja serije protesta protiv policijske brutalnosti.

Pokret BLM posebno je aktivan među studentskom populacijom imajući u vidu da njegove pripadnike čine mahom mladi obrazovani ljudi. Milenijalci (deca rođena tokom osme decenije 20. veka) i Generacija X (deca rođena tokom devete decenije 2o. veka) imaju znatno drugačije tumačenje istorije od svojih roditelja (engl. babyboomers) i spremni su da se suoče sa alternativnom istorijom Sjedinjenih Američkih Država koja je ispunjena problemima robovlasništva, eksploatacije, nejednakosti i rasne marginalizacije (Zinn 1980; Ross 2020). Upravo zbog toga, aktivnosti pokreta su se posebno osetile unutar univerziteta i kampusa. 
Svojim aktivnostima pokret BLM pokazao je da je, kao i u svakodnevnom životu, policijska ${ }^{4}$ brutalnost na kampusima usmerena pre svega prema pripadnicima Afro-američke zajednice koji u pojedinim slučajevima, kao što je Univerzitet u Čikagu, bivaju meta u 90\% slučajeva (Newman 2016). To je podstaklo niz zahteva upućenih prema univerzitetima koji su, usled novonastale situacije i društvenog pritiska, bili primorani da, i pored pogoršane ekonomske situacije, odvoje značajna sredstva za pitanja rasne jednakosti i veće inkluzije pripadnika manjinskih zajednica. U slučaju Nortvestern univerziteta, administracija se odlučila da kao odgovor na BLM proteste odvoji dodatnih 1.500.ooo dolara za unapređivanje društvene pravde i rasne jednakosti u Evanstonu (predgrađu Čikaga gde se nalazi kampus Univerziteta), da uloži 500.000 dolara u projekte saradnje sa lokalnim manjinskim zajednicama, kao i da intenzivira infrastrukturne projekte poput Crne kuće (engl. The Black House), čija svrha se tiče poboljšanja položaja manjinskih zajednica unutar samog Univerziteta (Morton Schapiro, imejl autoru, 14. jun 2020).

\section{Perspektive visokog obrazovanja u SAD}

Imajući u vidu sve prethodno navedeno, jasno je da dugoročna perspektiva visokog obrazovanja u Sjedinjenim Američkim Državama deluje neizvesno, najblaže rečeno. Uticaj epidemije će imati dugoročne negativne posledice, s tim što određeni aspekti, poput povećanog društvenog aktivizma, mogu dovesti i do određenih pozitivnih promena.

Kada je reč o negativnim posledicama tu svakako najvažnije mesto zauzima pitanje manjeg izdvajanja za obrazovanje. Kriza utiče na univerzitete na takav način da ponovo vraća pitanje strogih mera štednje koje su bile na snazi tokom ekonomske krize između 2008. i 2010. godine. Takve mere će neupitno dovesti do manje izdvajanja za školarine za nadarene studente ili one koji su u slabijoj materijalnoj situaciji. Nortvestern univerzitet je tokom trajanja krize odvojio 1.500.00o dolara za hitne potrebe ugroženih studenata, ali takve odluke su bile kratkoročne i ne mogu se ponovo očekivati u budućnosti, pogotovu ne u kontekstu tržišnog obrazovanja kakvo je u Sjedinjenim Američkim Državama. Pogoršana epidemiološka situacija u ovom zemlji, zajedno sa već objašnjenim porastom netrpeljivosti prema određenim etničkim grupama, učiniće američko visoko obrazovanje manje internacionalizovanim i posledično manje multikulturnim. Sve zajedno dovodi do smanjenog kvaliteta obrazovanja gde se upisni kriterijumi snižavaju kako bi se privukao veći broj studenata. Neke naznake

4 Univerziteti u Sjedinjenim Američkim Državama imaju sopstvenu policiju (engl. university police) koja se stara o sprovođenju reda u kampusima i drugim prostorijama u vlasništvu univerziteta. 
toga su već vidljive, kao što je promena načina ocenjivanja (prisutno i na Nortvestern univerzitetu) iz skaliranog u položio/nije položio.

Posledice će osetiti i predavači i drugo akademsko osoblje. Nekoliko puta spomenute mere štednje primoraće univerzitete da smanje broj akademskog osoblja, kao i da nude lošije uslove rada poput kratkotrajnih ugovora o radu ili nižu cenu rada. Navedeno se već dešava na Nortvestern univerzitetu gde je 187 ljudi dobrovoljno napustilo posao a 87 otpušteno kao posledica epidemije i smanjenih univerzitetskih prihoda (Morton Schapiro, imejl autoru, 5. avgust 2020). Pored toga, Univerzitet je odlučio da ne doprinosi više penzionom fondu zaposlenih, da zaustavi nova zaposlenja i da smanji plate akademskog menadžmenta. Slične mere se mogu očekivati i u budućnosti s tim da će njihov obim zavisiti od stanja na tržištu i posledica epidemije.

Dugoročno, može se očekivati da se u Sjedinjenim Američkim Državama smanji broj visokoškolskih institucija. Ozbiljnost krize je takva da mnoge manje škole (engl. Liberal Arts Colleges) neće biti u mogućnosti da se izbore sa finansijskim problemima. To je već sada evidentno jer su pojedine škole i univerziteti već zatvoreni ili je najavljeno njihovo zatvaranje. Po sprovedenim istraživanjima čak 345 visokoškolskih ustanova je u opasnosti od zatvaranja, što je za 110 više u odnosu na vreme pre epidemije (Fernandes 2020).

S tim u vezi je i povećanje nejednakosti u visokom obrazovanju. Sa zatvaranjem manjih škola smanjiće se mogućnosti za upis dece sa lošijim prosekom ili one koje imaju slabiji materijalni položaj. Imajući u vidu da je glavni način izlaska iz krize putem školarina elitni univerziteti će upisivati privilegovanu decu koja mogu da plate punu cenu školarina čime će se zatvoriti pristup onima koji zavise od finansijske pomoći (Hess 2020). Nažalost, to se ponajviše odnosi na pripadnike Afro-američke zajednice, a pogotovu ženski deo ove populacije.

Na kraju, treba istaći da će epidemija uticati i na sama istraživanja. Usled straha od zaražavanja, kao i mogućih troškova osiguranja i lečenja etički odbori univerziteta davaće sve manje saglasnosti za terenska istraživanja tamo gde je visoka stopa obolelih od COVID-19. To se odnosi na same Sjedinjene Američke Države, ali i za istraživanja koja se sprovode u drugim delovima sveta. Ovakav trend može samo negativno uticati na kvalitet istraživanja koja se budu sprovodila u budućnosti.

S druge strane, čini se da epidemija može imati i pozitivne, nenameravane, posledice po visoko obrazovanje u SAD, iako u ograničenom obimu. Ono se odnosi na pitanja društvene i rasne marginalizacije koja se, nakon svega što se desilo, ne mogu više zanemarivati. Univerziteti poput Nortvesterna već su počeli da donose odluke koje su odgovor na zahteve pokreta BLM i koje se tiču većeg broja zaposlenih iz redova Afro-američke, 
Latino i zajednice starosedelaca, kao i veći broj pripadnika ovih zajednica na rukovodećim mestima. Nortvestern je već imenovao potpredsednicu za jednakost koja dolazi iz Afro-američke zajednice, što su uradili i neki drugi univerziteti. S tim u vezi je i ispisivanje nove istorije univerziteta gde se naglasak stavlja na izučavanje robovlasništva, represije i izrabljivanja manjinskih zajednica što je, nažalost, zajednička karakteristika većine vodećih univerziteta u Sjedinjenim Američkim Državama imajući u vidu vreme kada su nastajali. Rušenje ili skidanje spomenika posvećenih važnim ličnostima Konfederacije na Univerzitetima Misisipi, Florida, Kentaki, Portland ili Oregon pokazatelj su koliko je ovo pitanje dobilo na važnosti u kontekstu epidemije kada se pokazuje da su pripadnici manjinskih zajednica ponovo najviše ugroženi usled njihovog neravnopravnog položaja.

\section{ZAKLJUČAK}

Visoko obrazovanje u Sjedinjenim Američkim Državama ozbiljno je pogođeno posledicama epidemije COVID-19. Kao što je epidemija najviše pogodila ovu zemlju usled nepostojanja univerzalnog zdravstvenog osiguranja, tako je i najviše uticala na visokoobrazovni sektor koji je u potpunosti zavistan od tržišta. Kao što je neoliberalni model doneo prednost američkim univerzitetima u odnosu na evropske (i druge regione), tako se i sada pokazuje kao njihov glavni nedostatak.

Dugoročno gledano, negativni uticaji daleko prevazilaze pozitivne promene kada su u pitanju univerziteti u SAD. Posledice epidemije, zajedno sa visokim stopama nejednakosti i zavisnosti od tržišta presudno će uticati na budućnost univerziteta. Uzeto zajedno, ovi procesi će dovesti do toga da visoko obrazovanje u ovom delu sveta bude manje internacionalizovano i manje podvrgnuto uticajima koji su dolazili iz različitih delova sveta i stvarali multikulturnu akademsku zajednicu. Istovremeno, kriza će ograničiti, već limitiran, pristup univerzitetima onima koji isti ne mogu da priušte, čime će obrazovanje ponovo postati privilegija bogatih.

Negativne tendencije navedene u ovom radu svakako ne mogu kratkotrajno uticati na promenu globalne slike gde bi primat američkih univerziteta bio zamenjen evropskim ili univerzitetima iz Azije. Međutim, dugoročno, ovakvi trendovi, ukoliko opstanu, mogu ozbiljno dovesti u pitanje tvrdnje da je američko univerzitetsko obrazovanje dominantno u globalnim razmerama. 
POLITIČKE PERSPEKTIVE

ČLANCI I STUDIJE

\section{LITERATURA}

ARWU. 2020. "Academic Ranking of World Universities". Available from: http:// www.shanghairanking.com/ARWU2020.html

BBC. 2020. "Trump Stands by China Lab Origin Theory for Virus". Available from: https://www.bbc.com/news/world-us-canada-52496098

Birenbaum, Garry. 2020. “Endowments: What Are They Good For?” Available from: https://dailynorthwestern.com/2020/o6/14/campus/endowments-what-arethey-good-for/

Cheung, Helier, Zhaoyin Feng and Boer Deng. 2020. "What Attacks on Asians Reveal about American Identity”. Available from: https://www.bbc.com/news/ world-us-canada-52714804

Dolonec, Danijela and Karin, Doolan. 2013. "Reclaiming the Role of Higher Education in Croatia: Dominantand Oppositional Framings”. In eds. Pavel Zgaga, Ulrich Teichler and John Brennan. The Globalisation Challenge for European Higher Education: Convergence and Diversity, Centres and Peripheries. Frankfurt am Main: Peter Lang.

Džuverović, Nemanja, and Goran Tepšić. 2020. "Neoliberal Co-Optation, Power Relations and Informality in the Balkan International Relations Profession”. International Relations, 34 (1): 84-104. doi.org/10.1177/0047117819897303

Džuverović, Nemanja. 2020. „Lečenje u vreme epidemije”. Dostupno preko: https:// americki-izbori.rs/lecenje-u-vreme-epidemije/

Bastrikin, Andrej. 2020. "International Student Enrollment Statistics". Available from: https://educationdata.org/international-student-enrollment-statistics

Fernandes, Deirdre. 2020. "Amid Coronavirus Pandemic, a Growing List of Colleges in Financial Peril”. Available from: https://www.bostonglobe.com/2020/05/o8/ metro/amid -pandemic-growing-list-colleges-financial-peril/

Gupta, Suman, Jernej Habjan, and Hrvoje Tutek. 2016. "Academia and the Production of Unemployment”. In eds. Suman Gupta, Jernej Habjan, and Hrvoje Tutek. Academic Labour, Academic Labour, Unemployment and Global Higher Education. London: Palgrave Macmillan.

Hess, Abigail. 2020. " 7 Ways the Coronavirus Pandemic Could Change College this Fall and Forever". Available from: https://www.cnbc.com/2020/o6/19/7-wayscoronavirus-pandemic-may-change-college-this-fall-and-forever.html

Kim, Hayoung, Charag Krishnan, Jonathan Lawand and Ted Rounsaville. 2020. "COVID-19 and US Higher Education Enrollment: Preparing Leaders for Fall”. Available from: https://www.mckinsey.com/industries/public-and-social-sector/our-insights/covid-19-and-us-higher-education-enrollment-preparing-leaders-for-fall 
Kowarski, Illana. 2020. "1o Universities with the Biggest Endowments”. Available from: https://www.usnews.com/education/best-colleges/the-short-list-college/articles/10-universities-with-the-biggest-endowments

Newman, Jonah. 2016. "New Data Supports Old Accusations of Racial Profiling by University of Chicago Police Department”. Available from: https://www. chicagoreporter.com/new-data-supports-old-accusations-of-racial-profiling-by-university-of-chicago-police-department/

Nicolson, Donald. 2017. Academic Conferences as Neoliberal Commodities. Cham: Palgrave Macmillan.

Pilkington, Ed. 2020. "Covid-19 Death Rate Among African Americans and Latinos Rising Sharply”. Available from: https://www.theguardian.com/world/2020/ sep/o8/covid-19-death-rate-african-americans-and-latinos-rising-sharply

Ross, Kihana Miraya. 2020. "Call it What it is: Anti-Blackness”. Available from: https://www.nytimes.com/2020/o6/o4/opinion/george-floyd-anti-blackness. html

The Times Higher Education. 2020. "World University Rankings 2020”. Available from: https://www.timeshighereducation.com/world-university-rankings/2020/world-ranking\#!/page/o/length/25/sort_by/rank/sort_order/asc/ cols/stats

US Bureau of Labor Statistics. 2020. “Civilian Unemployment Rate”. Available from: https://www.bls.gov/charts/employment-situation/civilian-unemployment-rate.htm

Zhang, Dianand and Mike Stucka. 2020. "COVID-19, Visas, Trump: International Students Turning Away from US Colleges for Lots of Reasons”. Available from: https://www.usatoday.com/story/news/education/2020/o8/19/covid-college-fall-semester-2020-international-student-visa-donald-trump/5585675002/

Zinn, Howard. 1980. A People's History of the United States. New York: Harper Collins.

\section{SUMMARY}

\section{The Impact of COVID-19 Pandemic on Higher Education IN THE US}

Higher education in the United States is the best in the world according to most quantitative and qualitativei ndicators. Universities in the United States, along with those in the United Kingdom, attract the best students not only from Europe but around the world, including the most populous countries and growing economies such as China, India, Brazil or Indonesia. At the same time, renowned professors and researchers mostly work in the United States, given the excellent working and research conditions. However, the strength of American universities is, at the same time, their weakness in the context of the 
POLITIČKE PERSPEKTIVE

ČLANCI I STUDIJE

COVID-19 epidemic. Most universities are private universities that depend entirely on the market, donations, and mostly student tuition. The epidemic has exacerbated the problem of marketing education in the United States, bearing in mind that most students are reconsidering the continuation of schooling due to economic uncertainty that the epidemic brings and uncertain labour market. Focusing on the case study of Northwestern University, the text is analyzing the economic and social consequences of the epidemic on higher education in the United States, as well as possible ways to overcome it.

KEYwORDS: higher education, USA, pandemic, COVID-19, Northwestern, crisis. 